\title{
Increase in Conductivity of the Surface of Heat Resisting Alloy by La-coating
}

\author{
Naoki OISHI, Tatsuru NAMIKAWA and Yohtaro YAMAZAKI*
}

Received February 4, 1997 ; Accepted April 14, 1997

\section{INTRODUCTION}

Separators are the key elements of planar SOFCs (Solid Oxide Fuel Cells) to develop performance and reliability of the system. Alloy separators have advantages with respect to electrical and thermal conductivity, mechanical strength, and machinability compared with the ceramic separators of $\mathrm{LaCrO}_{3}$. Heat resisting alloys with low-thermal-expansion ${ }^{1,2)}$ and stack structures relaxing thermal stresses ${ }^{3,4}$ have been investigated to reduce the thermal expansion mismatching in the cell stacks.

Most of these alloys form oxide layers of $\mathrm{Cr}_{2} \mathrm{O}_{3}$ or $\mathrm{Al}_{2} \mathrm{O}_{3}$ to establish heat resistivity at high temperatures. However, these scales decrease the cell performance because of their low electronic conductivity and the diffusion of chromium vapor species to the cathode in the case of $\mathrm{Cr}_{2} \mathrm{O}_{3}$ forming alloys. Applying functional coatings onto these alloys is being investigated in order to solve these problems ${ }^{5,6)}$.

In this study, we deposit La films onto a common heat resisting alloy, Inconel 600 , using electron beam evaporation, and the effects of the La-coating at high temperatures are examined.

\section{EXPERIMENTAL}

The preparation process of the La-coating is as follows. Inconel $600(\mathrm{Ni}:$ bal., $\mathrm{Cr}: 14-17 \%, \mathrm{Fe}: 6$ - $10 \%, \mathrm{Mn}:<1 \%, \mathrm{C}:<0.15 \%)$, Ni (99.7\%), Cr (99.9\%), and $\mathrm{Fe}(99.8 \%)$ sheets $(15 \mathrm{~mm} \times 15 \mathrm{~mm} \times 1$ $\mathrm{mm}$ ) were used as substrate. $\mathrm{La}(99.9 \%)$ was used as the evaporation source. Surfaces of the substrates were polished with $1 \mu \mathrm{m}$ diamond paste and cleaned in acetone with an ultrasonic cleaner. Then La was deDepartment of Electronic Chemistry, Interdisciplinary Graduate School of Science and Engineering, Tokyo Institute of Technology

(Nagatsuta, Midori-ku, Yokohama 226, Japan)

Key Words : SOFC, Heat resisting alloy, Resistance posited onto the substrate in a vacuum of $6 \times 10^{-3} \mathrm{~Pa}$ at a substrate temperature of $700{ }^{\circ} \mathrm{C}$. The voltage and emission current of the electron beam device were -10 $\mathrm{kV}$ and $150 \mathrm{~mA}$, respectively. Both sides of the substrate were coated with $\mathrm{La}$ in the same procedure. The coated area was $12 \mathrm{~mm}$ in diameter and the thickness was approximately $2 \mu \mathrm{m}$. The La-coated samples were heated at $900{ }^{\circ} \mathrm{C}$ for specified times.

The structure of the formed oxide was examined with XRD $(\mathrm{Cu} \mathrm{K \alpha})$ and the oxide scale was observed by SEM. The resistance of the sample treated at 900 ${ }^{\circ} \mathrm{C}$ was measured at elevated temperatures with the D.C. two probe method. Pt electrodes were attached to the both sides of the sample by firing $P t$ paste. A constant current of $0.10 \mathrm{~A}$ was applied through $\mathrm{Pt}$ leads attached to the electrodes and the voltage drop between both terminals was measured.

\section{RESULTS AND DISCUSSION}

The as-deposited La layer on Inconel 600 was uniform and adhered well to the substrate with no metallic luster. The color was dark gray. When $\mathrm{Cr}$ and $\mathrm{Fe}$ were used as substrate, these as-deposited La layers were rough in contrast to Inconel 600 and $\mathrm{Ni}$, and uniform La layers were not obtained. Around $700{ }^{\circ} \mathrm{C}$, the crystal structure of $\mathrm{Fe}$ and $\mathrm{Cr}$ is bce, while that of $\mathrm{Ni}$ is fcc. The phase transition from hexagonal to fcc of La system occurs at $310{ }^{\circ} \mathrm{C}$, and from fcc to bcc at $868^{\circ} \mathrm{C}$. Therefore, it is presumed that La forms uniform layers on $\mathrm{Ni}$ based alloys like Inconel 600 due to the same crystal structure at the substrate temperature of $700{ }^{\circ} \mathrm{C}$.

SEM image of a La-coated Inconel 600 treated at $900{ }^{\circ} \mathrm{C}$ in air for $250 \mathrm{~h}$ is shown in Fig. 1-(a). The coated surface was uniform and smooth compared with the uncoated surface as shown in Fig. 1-(b). In addition, some specific crystal growth in the oxide layer was not observed. 

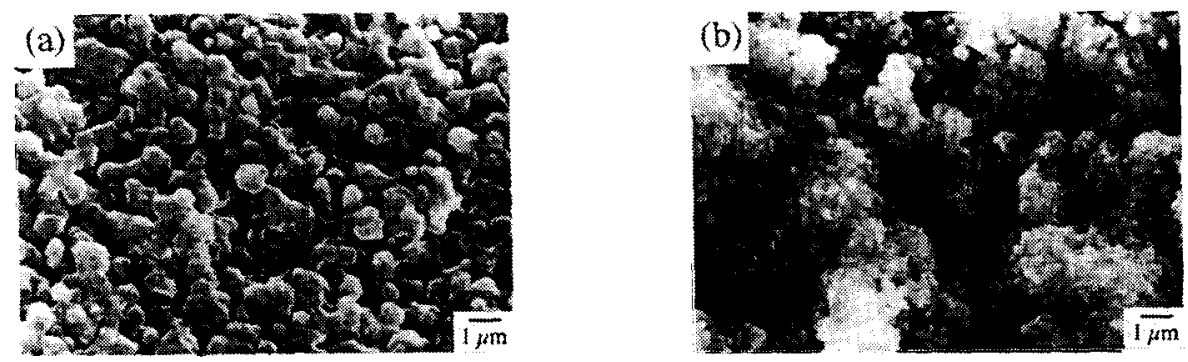

Fig.1 SEM images of (a) La-coated, and (b) uncoated surfaces of Inconel 600 after oxidation in air for $250 \mathrm{~h}$.

Figure 2 shows the room tempicrature XRD patterns of the sample shown in Fig. 1-(a) (Curve a), and the sample which was thermally treated in $\mathrm{H}_{2}$ at $900{ }^{\circ} \mathrm{C}$ for $5 \mathrm{~h}$ after oxidation in air at $900^{\circ} \mathrm{C}$ for $25 \mathrm{~h}$ (Curve b). Diffraction peaks of $\mathrm{LaCrO}_{3}$ were observed in Curve a, and sharp peaks from $\mathrm{NiO}$ were observed and small peaks from $\mathrm{Cr}_{2} \mathrm{O}_{3}$ were also detected. At high temperatures, $\mathrm{Cr}_{2} \mathrm{O}_{3}$ forms on Inconel 600 in a wide range of oxygen partial pressure because of its thermodynamic stability. In the presence of La, however, $\mathrm{LaCrO}_{3}$ is thermodynamically stable compared with other La complex oxides containing $\mathrm{Ni}$ or $\mathrm{Fe}^{\text {7 }}$, therefore $\mathrm{LaCrO}_{3}$ selectively forms under the oxidation atmosphere. It had been suggested that $\mathrm{LaCrO}_{3}$ is useful for a protective layer of alloy separators against the $\mathrm{Cr}$ species evaporation ${ }^{6}$. Therefore it is thought that the evaporation of $\mathrm{Cr}$ species from alloys is suppressed by coating with La. In Curve $b$, sharp peaks due to $\mathrm{Ni}$ were observed instead of NiO. From these results, it is thought that $\mathrm{Ni}$ and $\mathrm{Cr}$ diffused from the substrate into the La layer during the deposition, then $\mathrm{LaCrO}_{3}$ formed in the air at $900^{\circ} \mathrm{C}$, and $\mathrm{Ni}$ which could not react with La was simultaneously oxidized to $\mathrm{NiO}$. $\mathrm{NiO}$ in the coated layer was reduced to $\mathrm{Ni}$ in the $\mathrm{H}_{2}$ gas. In SOFCs, steam reforming of methane on Ni-YSZ cermet anode has been studied ${ }^{8)}$. Therefore it is expected that these $\mathrm{Ni}$ may work as reforming catalysts in the anode side of separators.

Figure 3 shows the resistance at the interface between $P t$ and the surfaces of the samples shown in Figs. 1-(a) and 1-(b). Since the measurement set up gives two resistances in series, it was divided by two and resistance in the alloy phase was neglected in this study. The resistance of La-coated Inconel 600 was lower than that of uncoated Inconel 600 by about a half order of magnitude. The resistance of La-coated and uncoated Inconel 600 at the end of this measurement was estimated to be 18 and $62 \mathrm{~m} \Omega \mathrm{cm}^{2}$, respectively.

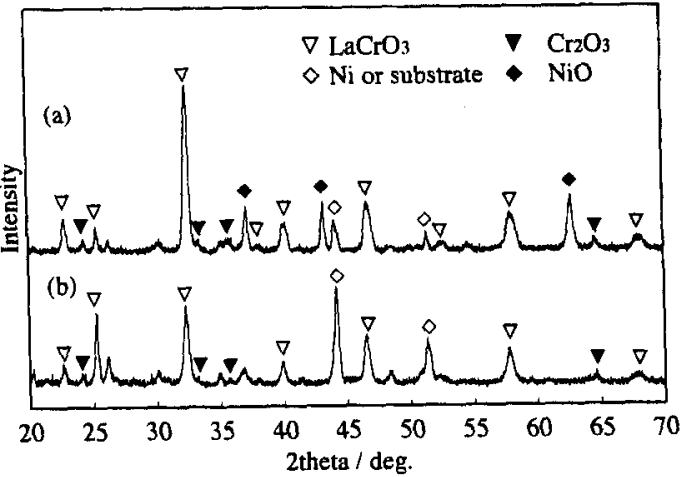

Fig. 2 XRD patterns of the surfaces of La-coated Inconel 600 substrates treated (a) in air at $900^{\circ} \mathrm{C}$ for $250 \mathrm{~h}$, and (b) in $\mathrm{H}_{2}$ gas at $900{ }^{\circ} \mathrm{C}$ for $5 \mathrm{~h}$ after oxidation in air at $900{ }^{\circ} \mathrm{C}$ for $25 \mathrm{~h}$.

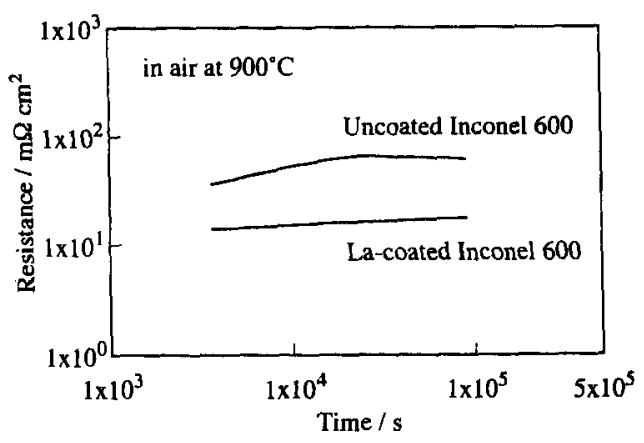

Fig.3 Resistance change in air at $900{ }^{\circ} \mathrm{C}$ as a function of time. Pretreatment of samples was in air at $900{ }^{\circ} \mathrm{C}$ for $250 \mathrm{~h}$.

\section{CONCLUSION}

In order to examine the effect of La coating onto heat resisting alloys at high temperatures, the surface of Inconel 600 was coated with La by electron beam evaporation. The following results were obtained. 
(1) The coated layer was uniform and smooth in comparison with the uncoated surface after heat treatment at $900{ }^{\circ} \mathrm{C}$ in air. $\mathrm{LaCrO}_{3}$ and $\mathrm{NiO}$ mainly formed in the coated surface.

(2) The resistance of La-coated Inconel 600 was lower than that of uncoated sample by about a half order of magnitude.

From these results, it is expected that La-coating onto Inconel 600 can decrease the electric resistivity and the volatility of $\mathrm{Cr}$ oxide which decreases performance and long term stability in SOFCs. In addition, it is suggested that the surface of La-coated Inconel 600 separator in the anode side functions as reforming catalysts.

\section{REFERENCES}

1) W. Qudakkers, H. Greiner, and W. Kock, Proc. 1st
European Solid Oxide Fuel Cell Forum, p.525 (1994).

2) M. Ueda and H. Taimatsu, The 3rd FCDIC Fuel Cell Symposium Proceedings, p.226 (1996).

3) N. Oishi, N. Tomita, T. Namikawa and Y. Yamazaki, Denki Kagaku, 62, 894 (1994).

4) N. Oishi, T. Namikawa and Y. Yamazaki, Denki Kagaku, 64, 620 (1996).

5) T. Kadowaki, T Shiomitsu, E. Matsuda, H. Nakagawa, H. Tsuneizumi and T. Maruyama, Solid State lonics, 67, 65 (1993).

6) H. Schmidt, B. Bruckner, and K. Fischer, Proc. 4th Int. Symp. Solid Oxide Fuel Cells, p. 869 (1995).

7) H. Yokokawa, N. Sakai, T. Kawada and M. Dokiya, Solid State Ionics, 52, 43 (1992).

8) S. Sridhar, K. C. Chou and U. B. Pal, Proc. 4th Int. Symp. Solid Oxide Fuel Cells, p. 829 (1995). 